Buana Sains Vol 19 No 2 : 23 - 30, 2019

\title{
Potensi Asap Cair dari Sekam untuk Meningkatkan Pertumbuhan dan Produksi Padi (Oryza sativa L.)
}

\section{Istiqomah dan Dian Eka Kusumawati}

\author{
Universitas Islam Darul 'Ulum Lamongan
}

\begin{abstract}
Rice is the main staple food in Indonesia. The high needs of national rice must be balanced with the high production of rice crops. One of the efforts to increase the production of rice is the application of liquid smoke originated from agricultural waste, namely husk. The research was aimed to determine the effect of the application of husk liquid smoke on rice growth and production. The research used a single-factor randomized block design (RBD) with 5 treatments and 5 replications. The treatments consisted of several concentrations of liquid smoke : $0 \%$ (control), $0.5 \%, 1 \%, 2 \%$, and $3 \%$. This research employed several stages; land processing, seedling nursery, rice planting, applicating the liquid smoke, fertilizing, maintaining plants, and harvesting. The results showed that the application of husk liquid smoke significantly affected all observational parameters. On the parameters of rice growth and production, the application of $2 \%$ liquid smoke showed the best result. The plant height increased by $25.80 \%$ and the number of tillers increased by $49.70 \%$ compared to the control. The highest increase is in the number of grains per panicle and the weight of 1000 grains was $4,984 \%$ and $26.78 \%$ respectively.
\end{abstract}

Keywords: Growth; husk; liquid smoke; production; rice.

\section{Pendahuluan}

Padi adalah jenis tanaman pangan utama di Indonesia. Hal ini dikarenakan sebagian besar masyarakat Indonesia mengkonsumsi beras sebagai bahan pangan utama dibandingkan jenis bahan pangan lainnya seperti jangung dan umbi-umbian. Tingginya kebutuhan beras nasional harus diimbangi dengan tingginya produksi panen tanaman padi. Upaya yang dapat dilakukan untuk meningkatkan produksi padi diantaranya melalui pengoptimalan teknis budidaya tanaman, perlindungan tanaman dari hama dan organisme penyebab penyakit, penanaman varietas unggul, dan penggunaan pupuk padat atau cair yang dapat merangsang pertumbuhan tanaman (Amiroh, Istiqomah, \& Sholekan, 2018).
Salah satu alternatif untuk meningkatkan pertumbuhan dan produksi padi yaitu dengan pemberian asap cair.

Asap cair adalah hasil kondensasi dari uap hasil pembakaran (pirolisis) secara langsung atau tidak langsung dari bahan-bahan yang banyak mengandung karbon serta senyawa-senyawa lain seperti selulosa, hemiselulosa, dan lignin (La Tima, 2016). Asap cair memiliki pengaruh positif bagi tanaman yaitu meningkatkan kualitas tanah dan menetralisir keasaman tanah, menangkal serangan hama dan patogen tanaman, sebagai stimulan pertumbuhan tanaman pada akar, batang, umbi, daun, bunga, dan buah (Basri, 2010). Hasil penelitian Komarayati dan Pari (2014) menyatakan bahwa penambahan arang dan asap cair dari bahan baku kayu dapat 
Istiqomah dan D. E. Kusumawati/ Buana Sains Vol 19 No 2 : 23-30

mempercepat pertumbuhan anakan jabon dan sengon.

Bahan baku asap cair dapat berasal dari limbah pertanian. Limbah pertanian adalah sisa hasil kegiatan pertanian yang berpotensi menimbulkan permasalahan lingkungan karena belum adanya pengolahan menjadi barang yang bermanfaat. Sekam padi adalah sisa penggilingan gabah yang belum termanfaatkan secara optimal. Kondisi ini menyebabkan jumlahnya melimpah dan menganggu kebersihan lingkungan. Sekam termasuk jenis limbah organik yang sukar dikomposkan. Hal ini dikarenakan teksturnya yang tidak lunak dan tidak gampang terurai. Penanganan efektif untuk limbah sekam adalah dengan cara pengarangan (pirolisis) yang menghasilkan arang dan asap cair. Pengolahan limbah organik menjadi arang dan asap cair memberi banyak manfaat diantaranya dapat menekan volume timbunan limbah dan juga dapat dimanfaatkan sebagai pembangun kesuburan tanah (Gusmailina dan Pari, 2002). Hasil penelitian Ariyani et al. (2015) menyatakan bahwa asap cair yang dihasilkan dari sekam padi memiliki senyawa yang lengkap, diantaranya yaitu fenol, karbonil, dan asam. Tiga kandungan unsur dalam asap cair sekam ini bermanfaat sebagai pemicu pertumbuhan tanaman namun perlu diteliti lebih lanjut pengaruhnya terhadap tanaman padi. Tujuan penelitian ini adalah untuk mengetahui pengaruh aplikasi asap cair dari sekam terhadap pertumbuhan dan produksi padi.

\section{Metode Penelitian}

Penelitian ini dilaksanakan di
Desa Centini, Kecamatan Laren,
Kabupaten Lamongan. Ketinggian
tempat kurang lebih 8 meter di atas
permukaan laut (mdpl). Penelitian

dilaksanakan pada bulan April hingga Agustus 2019.

Penelitian ini menggunakan metode Rancangan Acak Kelompok (RAK) berfaktor tunggal yang terdiri dari 5 perlakuan dan 5 ulangan. Perlakuan dilakukan pada beberapa konsentrasi asap cair yaitu konsentrasi $0 \%$ (kontrol), $0.5 \%, 1 \%, 2 \%$, dan $3 \%$ (v/v).

\section{Bahan dan alat}

Bahan yang digunakan yaitu asap cair dari sekam, padi varietas Ciherang, pupuk petroganik, pupuk urea, phonska $\left(15 \% \mathrm{~N}, 15 \% \mathrm{P}_{2} \mathrm{O}_{5}, 15 \% \mathrm{~K}_{2} \mathrm{O}, 10 \% \mathrm{~S}\right)$, fungisida, herbisida, dan bakterisida. Peralatan yang digunakan antara lain alat pengolah tanah, alat semprot (sprayer), meteran, timbangan manual dan analitik, serta alat penunjang lainnya.

\section{Pelaksanaan Penelitian \\ Pengolahan lahan}

Pembajakan lahan sawah dilakukan dengan traktor tangan yang bertujuan untuk membalik lapisan tanah dan melapukkan sisa tanaman atau gulma. Petakan dibuat sebanyak 25 petak dengan luas masing-masing petak $4 \mathrm{~m}^{2}$. Pada samping kanan dan kiri petakan dibuat saluran drainase agar tidak tergenang saat hujan.

\section{Persemaian bibit padi}

Benih padi yang digunakan adalah varietas Ciherang. Sebelum dilakukan penaburan, benih terlebih dahulu direndam selama 24 jam kemudian diperam dalam karung selama 24 jam. Benih yang telah berkecambah kemudian ditaburkan pada lahan yang telah disiapkan. Bibit padi dipindah tanam pada usia 20 hari setelah semai.

\section{Penanaman padi}

Penanaman dimulai dari pemindahan padi yang ada di bedengan ke lahan sawah dengan kedalaman sekitar 2-3 cm dan kondisi air macak-macak. 
Jumlah bibit yang ditanam yaitu 2 rumpun bibit padi per lubang dengan jarak tanam $20 \mathrm{~cm} \times 20 \mathrm{~cm}$. Perpetak terdiri dari 100 tanaman.

\section{Aplikasi asap cair sekam}

Aplikasi asap cair dilakukan mulai padi berumur 15 hari setelah tanam (HST) hingga 60 HST dengan interval pemberian 7 hari sekali. Asap cair disemprotkan menggunakan tangki sprayer $14 \mathrm{~L}$ pada pagi hari.

\section{Pemupukan dan pemeliharaan tanaman}

Pada penelitian ini pupuk petroganik diberikan saat pengolahan tanah. Pupuk urea dan phonska diberikan sebanyak tiga kali yaitu pada 18 HST, 32 HST, dan 51 HST. Pemeliharaan tanaman dilakukan dengan memantau kondisi air di lahan sawah dan pengendalian panyakit tanaman. Pengendalian penyakit yang disebabkan oleh patogen jamur dengan fungisida sedangkan patogen bakteri dengan bakterisida. Herbisida hanya diaplikasikan saat sebelum pengolahan lahan (pra-tanam), penyiangan pada lahan sawah dilakukan secara manual.

\section{Pemanenan}

Pemanenan dilakukan manual dengan sabit kemudian bulir dirontokkan dengan perontok bermesin diesel. Panen dilakukan saat tanaman berumur 100-110 hari setelah semai yang ditandai dengan bulir padi yang padat, keras dan berwarna kuning.

\section{Pengamatan dan Pengolahan Data}

Parameter pertumbuhan dan produksi padi yang diamati adalah tinggi tanaman, jumlah anakan, jumlah gabah per malai, dan berat 1000 bulir. Pengamatan dilakukan mulai padi berumur 22 HST (satu pekan setelah aplikasi pertama) dengan interval 7 hari sekali. Data yang diperoleh dari hasil pengamatan dianalisis menggunakan analisis ragam (uji F) pada taraf 5\%. Apabila uji $\mathrm{F}$ menunjukkan hasil yang berbeda nyata maka dilanjutkan dengan uji beda nyata terkecil (BNT) pada taraf $5 \%$.

\section{Hasil dan Pembahasan}

\section{Tinggi Tanaman}

Hasil analisis ragam menunjukkan adanya pengaruh yang nyata antara pemberian asap cair pada berbagai kosentrasi terhadap tinggi tanaman. Rerata tinggi tanaman padi disajikan pada Tabel 1.

Hasil pengamatan menunjukkan bahwa rerata tinggi tanaman padi pada seluruh perlakuan asap cair memberikan hasil yang lebih tinggi dibandingkan dengan kontrol. Perlakuan asap cair 0.5\% menunjukkan hasil yang lebih tinggi daripada kontrol namun bukan merupakan hasil yang terbaik. Asap cair 1\%-3\% menghasilkan tinggi tanaman yang sama secara statistika. Peningkatan tinggi tanaman terbesar dihasilkan oleh perlakuan pemberian asap cair $2 \%$.

Tabel 1. Rerata peningkatan tinggi tanaman padi

\begin{tabular}{ccc}
\hline Konsentrasi asap cair $(\%)$ & Tinggi tanaman $(\mathrm{cm})$ & Peningkatan $(\%)$ \\
\hline 0 (kontrol) & $71.10 \mathrm{c}$ & - \\
0.5 & $81.06 \mathrm{~b}$ & 14.70 \\
1 & $87.98 \mathrm{a}$ & 23.70 \\
2 & $89.50 \mathrm{a}$ & 25.80 \\
3 & $88.70 \mathrm{a}$ & 24.70 \\
\hline
\end{tabular}

BNT $(5 \%) \quad 1.61$

Keterangan : Angka diikuti oleh huruf yang sama pada kolom yang sama menunjukkan tidak berbeda nyata pada uji BNT 5\%. 
Istiqomah dan D. E. Kusumawati/ Buana Sains Vol 19 No 2 : 23-30

\section{Jumlah Anakan Padi}

Pemberian asap cair memiliki pengaruh yang nyata terhadap jumlah anakan padi. Perbedaan yang nyata antara aplikasi asap cair sekam terhadap jumlah anakan padi disajikan pada Tabel 2.

Jumlah anakan padi pada seluruh perlakuan asap cair sekam memberikan hasil yang lebih tinggi dibandingkan dengan kontrol. Asap cair $0.5 \%$ menunjukkan jumlah anakan lebih tinggi dibandingkan kontrol tetapi lebih rendah jika dibandingkan dengan konsentrasi lainnya. Asap cair 1\% dan $3 \%$ menunjukkan hasil yang sama secara statistika. Hal ini menunjukkan bahwa pemberian asap cair pada kedua konsentrasi ini mampu meningkatkan jumlah anakan pada kisaran yang sama. Perlakuan asap cair terbaik yaitu konsentrasi $2 \%$ dengan peningkatan jumlah anakan sebesar $49.70 \%$.

\section{Jumlah Gabah per Malai}

Hasil pengamatan terhadap jumlah gabah per malai menunjukkan bahwa pada tanaman padi yang diberi asap cair sekam memiliki jumlah gabah per malai lebih banyak dibandingkan kontrol. Rerata jumlah gabah per malai disajikan pada Tabel 3. Rerata jumlah gabah per malai pada asap cair 0.5\% lebih besar dibandingkan kontrol tetapi paling kecil dibandingkan dengan konsentrasi asap cair lainnya. Pada asap cair sekam 1\%-3\% menghasilkan jumlah gabah per malai yang sama secara statistika. Peningkatan jumlah gabah per malai tertinggi dihasilkan oleh perlakuan asap cair sekam 2\% yaitu sebesar $4.984 \%$.

Tabel 2. Rerata peningkatan anakan tanaman padi

\begin{tabular}{ccc}
\hline Konsentrasi asap cair $(\%)$ & Jumlah anakan & Peningkatan $(\%)$ \\
\hline 0 (kontrol) & $22.52 \mathrm{~d}$ & - \\
0.5 & $25.86 \mathrm{c}$ & 14.83 \\
1 & $29.28 \mathrm{~b}$ & 30.01 \\
2 & $33.72 \mathrm{a}$ & 49.70 \\
3 & $30.06 \mathrm{~b}$ & 33.40 \\
\hline BNT $(5 \%)$ & 1.83 &
\end{tabular}

Keterangan : Angka diikuti oleh huruf yang sama pada kolom yang sama menunjukkan tidak berbeda nyata pada uji BNT 5\%.

Tabel 3. Rerata jumlah gabah per malai

\begin{tabular}{ccc}
\hline Konsentrasi asap cair $(\%)$ & Jumlah gabah per malai & Peningkatan $(\%)$ \\
\hline 0 (kontrol) & $101.52 \mathrm{c}$ & - \\
0.5 & $103.90 \mathrm{~b}$ & 2.344 \\
1 & $105.82 \mathrm{a}$ & 4.235 \\
2 & $106.58 \mathrm{a}$ & 4.984 \\
3 & $105.78 \mathrm{a}$ & 4.196 \\
\hline BNT $(5 \%)$ & 1.82 &
\end{tabular}

Keterangan : Angka diikuti oleh huruf yang sama pada kolom yang sama menunjukkan tidak berbeda nyata pada uji BNT 5\%. 
Istiqomah dan D. E. Kusumawati/ Buana Sains Vol 19 No 2 : 23-30

\section{Berat 1000 Bulir Padi}

Hasil analisis ragam menunjukkan adanya pengaruh yang nyata antara pemberian asap cair pada berbagai kosentrasi terhadap berat 1000 bulir. Rerata tinggi berat 1000 bulir disajikan pada Tabel 4. Berat 1000 bulir padi pada seluruh perlakuan asap cair sekam memberikan hasil yang lebih tinggi dibandingkan dengan kontrol.. Perlakuan terbaik dihasilkan oleh asap cair $2 \%$ dengan peningkatan sebesar $26.78 \%$.

Berdasarkan hasil analisis ragam dari beberapa parameter pengamatan, yaitu meliputi fase vegetatif (tinggi tanaman dan jumlah anakan) dan fase generatif (jumlah gabah per malai dan berat 1000 bulir) diketahui bahwa pemberian asap cair sekam pada berbagai konsentrasi memberikan pengaruh nyata dibandingkan dengan kontrol (tanpa pemberian asap cair sekam). Hal ini membuktikan bahwa asap cair sekam merupakan larutan yang dapat berfungsi memicu pertumbuhan tanaman. Hasil Penelitian Yatagai (2002) menunjukkan bahwa kandungan asap cair (cuka kayu) seperti asam asetat dan metanol dapat mempercepat pertumbuhan tanaman.

Peningkatan tinggi tanaman, jumlah anakan, jumlah gabah per malai, dan berat 1000 bulir tidak bersifat linier. Peningkatan pertumbuhan dan produksi padi terhadap konsentrasi asap cair disajikan pada Gambar 1.

Tabel 4. Rerata berat 1000 bulir padi

\begin{tabular}{ccc}
\hline Konsentrasi asap cair $(\%)$ & Berat 1000 bulir $(\mathrm{gr})$ & Peningkatan $(\%)$ \\
\hline 0 (kontrol) & $21.88 \mathrm{c}$ & - \\
0.5 & $23.36 \mathrm{bc}$ & 6.764 \\
1 & $24.52 \mathrm{~b}$ & 12.06 \\
2 & $27.74 \mathrm{a}$ & 26.78 \\
3 & $24.00 \mathrm{~b}$ & 9.689 \\
\hline
\end{tabular}

BNT $(5 \%)$

Keterangan : Angka diikuti oleh huruf yang sama pada kolom yang sama menunjukkan tidak berbeda nyata pada uji BNT 5\%.

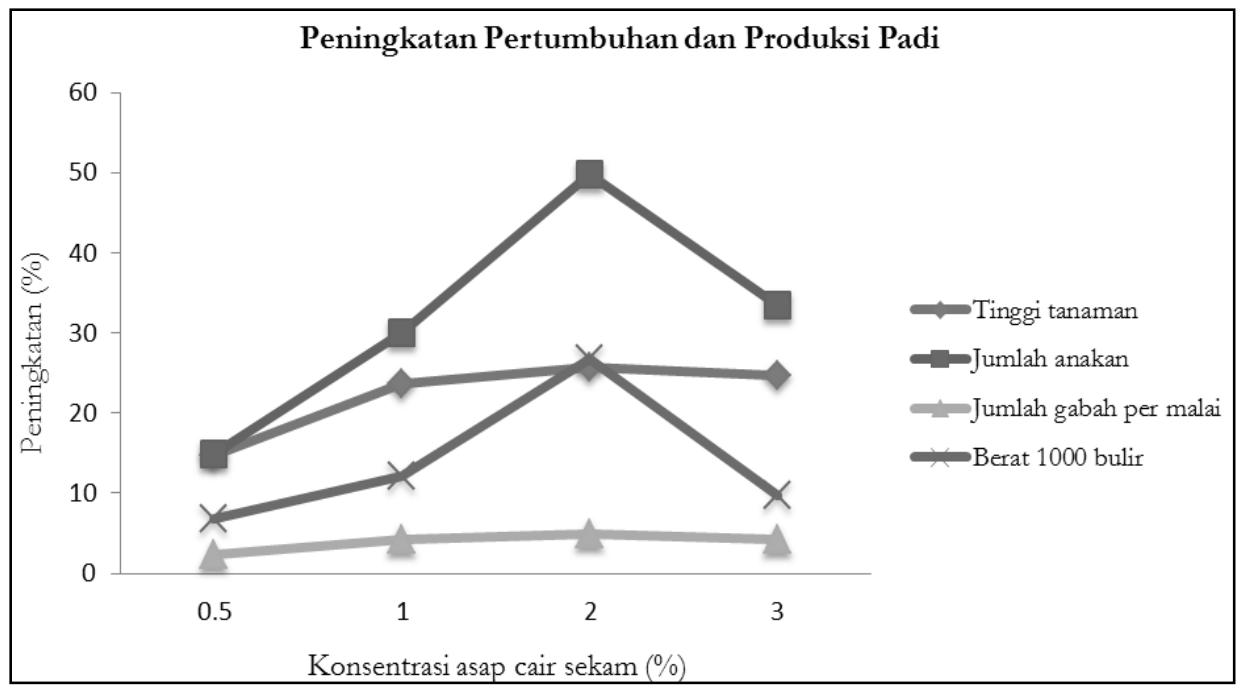

Gambar 1. Grafik peningkatan pertumbuhan dan produksi padi terhadap konsentrasi asap cair 
Istiqomah dan D. E. Kusumawati/ Buana Sains Vol 19 No 2 : 23-30

Pada pemberian asap cair $0.5 \%$ $2 \%$ terjadi peningkatan pada tinggi tanaman, jumlah anakan, jumlah gabah per malai, dan berat 1000 bulir. Hasil penelitian Komarayati dan Pari (2012) menunjukkan bahwa penambahan cuka kayu (asap cair) sebesar 2\% pada media tanam campuran arang dapat meningkatkan pertumbuhan anakan jabon sebesar 21,05-23,59 kali lipat, dibandingkan dengan penambahan cuka kayu sebesar $1 \%$ peningkatan hanya sebesar 8,20-8,56 kali lipat.

Penelitian pemberian asap cair pada tanaman padi pernah dilakukan oleh Sajuri dan Darjanto (2017) yang menunjukkan bahwa pemberian asap cair yang terbuat dari tempurung kelapa pada dosis 1:200 $(0.5 \%)$ dan dosis 1:400 $(0.25 \%)$ telah memberikan peningkatan pertumbuhan tinggi tanaman, jumlah daun, luas daun dan jumlah anakan. Hal ini diduga bahwa salah satu kandungan asap cair sekam adalah asam asetat yang merupakan prekusor dari hormon pertumbuhan tanaman yaitu auksin. Fungsi auksin yaitu mempengaruhi pertambahan panjang dan diameter batang, pertumbuhan dan perkembangan akar (Arimarsetiowati dan Ardiyani, 2012). Asap cair juga berpengaruh terhadap aspek generatif tanaman padi. Pirolisis sekam yang merupakan senyawa organik selulosa dan hemi selulosa mengandung senyawa karrikinolide (butenolide) yang dapat mempengaruhi jumlah dan umur keluarnya malai (Light et al., 2010).

Pada pemberian asap cair sekam $3 \%$ terjadi penurunan pertumbuhan dan produksi padi dibandingkan asap cair $2 \%$. Terdapat banyak faktor yang mempengaruhi penurunan pertumbuhan tanaman oleh pemberian asap cair dengan konsentrasi tinggi, salah satunya yaitu $\mathrm{pH}$. Hasil penelitian Jaya et al. (2016) menunjukkan bahwa penambahan asap cair berpegaruh negatif pada tanaman dengan sistem hidroponik, kangkung yang diberi asap cair tidak dapat bertahan lama. Tanaman dengan media tumbuh yang bersifat terlalu basa atau terlalu asam mengalami permasalahan dalam penyerapan nutrisi. Komarayati et al. (2014) memperkuat opini bahwa pemberian cuka kayu 2\% menghasilkan rata-rata pertambahan tinggi anakan sengon tertinggi yaitu $156,33 \mathrm{~cm}$ dan terendah dengan cuka kayu 4\% yaitu sebesar 75,68 cm.

\section{Kesimpulan}

Pemberian asap cair sekam pada berbagai konsentrasi dapat meningkatkan pertumbuhan dan produksi padi. Peningkatan terbesar pada tinggi padi, jumlah anakan, jumlah gabah per malai, dan berat 1000 butir dihasilkan oleh perlakuan asap cair sekam $2 \%$. Konsentrasi asap cair sekam 3\% justru menghasilkan penurunan pertumbuhan dan produksi padi dibandingkan asap cair $2 \%$. Konsentrasi asap cair sekam yang efektif dan efisien dalam meningkatkan pertumbuhan dan produksi padi adalah $2 \%$.

\section{Ucapan Terima Kasih}

a. Direktorat Riset dan Pengabdian kepada Masyarakat (DRPM) Kementerian Riset, Teknologi dan Pendidikan Tinggi yang membiayai kegiatan ini pada skema Penelitian Dosen Pemula (PDP), tahun 2019.

b. Lembaga Penelitian dan Pengabdian Masyarakat (LPPM) Universitas Islam Darul 'Ulum Lamongan yang telah memfasilitasi terlaksananya penelitian ini. 


\section{Daftar Pustaka}

Amiroh, A., Istiqomah, I., \& Sholekan, S. (2018). Aplikasi Macam Pupuk Organik dan Pupuk Kimia Majemuk Terhadap Pertumbuhan dan Produksi Padi (Oryza sativa L.) dengan Sistem Jajar Legowo. AGRORADIX: Jurnal Ilmu Pertanian, 2(1), 47-54.

Arimarsetiowati, R., \& Ardiyani, F. (2012). Pengaruh penambahan auxin terhadap pertunasan dan perakaran kopi arabika perbanyakan Somatic Embryogenesis (The effects of shooting and rooting of arabica coffee propagation through Embryogenesis Somatic auxin uses). Pelita Perkebunan (a Coffee and Cocoa Research Journal), 28(2), 8290.

Ariyani, D., Rasy, M., \& Harlianto, D. U. Y. A. (2015). Studi Kajian Kandungan Senyawa Pada Asap Cair dari Sekam Padi. In Prosiding Seminar Nasional Kimia FMIPA Universitas Negeri Surabaya (p. ISBN: 978-602-0951-05-8).

Basri, A. B. (2010). Manfaat asap cair untuk tanaman. Jurnal Serambi Pertanian, 4(5).

Budijanto, S., Hasbullah, R., Prabawati, S., Setiadjit, S., Sukarno, S., \& Zuraida, I. (2008). Kajian keamanan asap cair tempurung kelapa untuk produk pangan. Jurnal Ilmu Pertanian Indonesia, 13(3), 194203.

Gusmailina, G., \& Pari, G. (2002). Pengaruh Pemberian Arang Terhadap Pertumbuhan Tanaman Cabai Merah (Capsicum Annum). Jurnal Penelitian Hasil Hutan, 20(3), 217-229.
Jaya, J. D., Zulmi, A., Wahyudi, D., Kartika, K., Wati, H., Yuliana, N., \& Kholis, N. (2016). Optimasi Pembuatan Asap Cair dari Sekam Padi dan Aplikasinya sebagai Pupuk Tanaman Hidroponik. Jurnal Teknologi Agro-Industri, 2(2), 2832.

Komarayati, S., \& Pari, G. (2012). Arang hayati dan turunannya sebagai stimulan pertumbuhan jabon dan sengon. Buana Sains, 12(1), 1-6.

Komarayati, S., \& Pari, G. (2014). Kombinasi Pemberian Arang Hayati dan Cuka Kayu terhadap Pertumbuhan Jabon dan Sengon. Jurnal Penelitian Hasil Hutan, 32(1), 12-20.

La Tima, S. (2016). Pemanfaatan Asap Cair Kulit Biji Mete sebagai Pestisida. Journal of Chemical Process Engineering, 1(2).

Light, M. E., Burger, B. V, Staerk, D., Kohout, L., \& Van Staden, J. (2010). Butenolides from plantderived smoke: natural plant-growth regulators with antagonistic actions on seed germination. Journal of Natural Products, 73(2), 267-269.

Ningsih, L. S. (2011). Pembuatan Asap Cair dari Sekam Padi dengan Proses Pirolisa untukMenghasilkanInsektisidaOrga nik. Skrip Si. repository.unand.ac.id

Sajuri, S., \& Darjanto, D. (2017). Tumpangsari Padi-Rumput dan Aplikasi Asap Cair Tempurung Kelapa Terhadap Pertumbuhan, Fisiologi dan Hasil Padi Gogo. Pena Jurnal Ilmu Pengetahuan Dan Teknologi, 31(2), 37-50. 
Yatagai, M. (2002). Utilization of Chorcoal and wood vinegar in japan. Graduate School of Agricultural and Life Sciences. The University of Tokyo. Journal of Food Science Utilization of Charcoal and Wood Vinegar in Japan. 